\title{
DECLINE OF ELITE CONSENSUS AND DESTABILISATION OF POLITICAL SPACE IN EAST-CENTRAL EUROPE
}

\author{
MATEVZ TOM $\check{S} I \check{C}^{\prime}$
}

\begin{abstract}
The article deals with recent developments in terms of elite configuration and its impact on political stability in post-communist countries from East-Central Europe, especially with regard to the structure of political/party space. The author observes that none of the countries from this region has a political space that matches those of established democracies, where the key role is played by two parties, one on the left and another on the right of the political center. The claim is made that these developments are strongly related to an increase in polarization within the political elite, and the corresponding decline in elite consensus, resulting in the weakening of the potential for cooperation between elite factions. It is argued that this decline is only partially conditioned by global crisis, but is more significantly correlated to the specific nature of the transformation process.
\end{abstract}

KEYWORDS: elite, crisis, transition, post-communism

\section{INTRODUCTION}

The success (or failure) of the societal transformation of post-communist societies strongly depends on their ability to create conditions for the social self-organization and participation of different autonomous actors in the policymaking process. The formal installation of institutions of a parliamentary democracy, based on political competition and government that enjoys majoritarian support of the citizenry, is a necessary but not a sufficient condition for the successful completion of the democratic transition (Tomšič 2016). In this regard, the key role is played by the political elite who can be defined, according

1 Matevz Tomšič is professor of sociology at SASS, Nova Gorica; e-mail: matevz.tomsic@fuds.si 
to Higley and Burton (2006:7), as "persons who are able, by the virtue of their strategic positions in powerful organisations and movements, to affect political outcomes regularly and substantially." It can be perceived that the main agents of systemic change in the course of development of these societies, as well as the extent and tempo of such change, strongly depend on their way of conduct. However, their impact varies substantially, since it depends on socio-historical circumstances; i.e., "it is enlarged or constrained by the elites from other realms (e.g. from the economy), by their voters and the entire population, and finally by the institutional, political, economic and cultural context elites are embedded in" (Vogel and Rodriguez-Teruel 2016: 9).

The course of the development of former communist countries in the East Central Europe thus depends strongly on the character of the national political elite, since this plays a crucial role in the process of forming the institutional framework that determines the activities of actors in different social spheres. The configuration of the elite (i.e., the relationships between different elite factions, as well as their prevalent value patterns) influences the nature of political regimes, as well as the mode of regulating relations in economic and other social fields in a particular country (Adam et al. 2009; Tomšič 2016).

This article deals with recent developments in terms of elite configuration and its impact on political stability in post-communist countries from EastCentral Europe (focusing on countries from the region that became members of the EU in 2004), especially with regard to the structure of political/party space. It thematizes the level of consensus between different factions of the political elite which is, according to democratic elite theory, a precondition for the stabilization of democracy. We observe that, at the moment, none of the countries from the region has a political space that matches those of established democracies, where the key role is continuously played by two major parties, one on the left and another on the right of the political center. Even the countries where this used to be the case - like the Czech Republic and Slovenia - have experienced destabilization of the political space and deconsolidation of political parties in recent years. Stability of party structure and the ability to maintain a consensual type of political elite are significantly interconnected. Consensus can be achieved only when inter-party relations are transparent; i.e., when a rather limited set of political competitors is able to elaborate and pursue their policy orientations - provided they share basic norms and values. We claim that the above-mentioned developments are strongly correlated to an increase in polarization within the political elite, and a corresponding decline in elite consensus, resulting in a weakening of the potential for cooperation between elite factions. This decline is only partially and indirectly conditioned by the global crisis. It is more significantly related to the specifics of the transformation 
process and relations within the political elite. These developments, and the corresponding stagnation and in some cases even backsliding in terms of the quality of democracy, question the strength of the initial consensus within national elites.

\section{ELITES AS AGENTS OF DEMOCRATIC DEVELOPMENT}

Social theories dealing with the phenomenon of elites in contemporary societies differ from each other, especially in regard to their conception of power structures and power relations. Some of them - for example, theories of ruling classes, (Neo-)Marxist theories, and theories of ruling elites - claim that, in Western societies, power is strongly concentrated in individual centers of power which are closely interconnected and whose interests are identical (HoffmannLange 1992: 98). In his famous study on the 'power elite', C. Wright Mills (1956) stated that American society is dominated by a ruling class as a cohesive group composed of key people from political, business and military circles. On the other hand, adherents of pluralist theory claim that in contemporary democratic societies power is relatively dispersed, meaning there exists a situation whereby no group, no matter how well equipped with different strategic resources, is in a position to exert social hegemony. In this way, one cannot speak about the elite as a ruling class but about different elite factions that pursue different interests and thus often oppose each other. Robert Dahl $(1956,1989)$ declares modern democracy to be a 'polyarchy'; a phenomenon created by the dispersed rule of heterogeneous social powers, based on participation of the citizenry (that refers both to the right of people to select power holders, and to the possibility to participate with their proposals in the decision-making process), the equality of individual votes, and respect for and exertion of the legitimate will of the majority. A relative deconcentration of power (in comparison to other political regimes) is also manifest in the ability of different social and political groups (including protest ones) to integrate into the political process (Etzioni-Halevy 1990: 210).

Those theorists who see social and political power as concentrated perceive the role of elites as problematic from a democratic perspective since - they argue - it curtails the participation of ordinary citizens in the political process and hinders their exercise of control over power-holders, while other approaches claim that the existence of elites is not incompatible with democratic principles. From the so-called elite-pluralist (or elite-democratic) perspective, elites (particularly the ruling elite) are the key players in society in terms of their exertion of power and 
ability to make decisions about the most relevant matters; however, they do not represent a unified conglomerate of power, but a set of relatively autonomous groups. The structure of modern elites is, as already acknowledged by Weber (1978), complex and diverse. Further, their range of action is considerably limited through mechanisms that enable non-elites to exercise certain forms of control over the elite's conduct. In this regard, elites are perceived not as inhibitors of democracy, but as agents of its stability and development. As stated by Best and Higley (2010: 9): "Democratic elitism portrays elites as democracy's guardians, without whose protection democracy would probably unravel". Elite settlement in terms of compliance by different elite factions is the key condition for the consolidation of democratic systems and the stable functioning of political life in accordance with democratic norms and principles.

In order for elites to perform their democratic function, certain conditions have to be fulfilled. We speak here about elite autonomy, pluralism and professionalism. The very autonomy of elites is meant to be one of the characteristics of democratic order (Etzioni-Halevy 1993) where every faction of the political elite follows its own agenda, pursues interests of its own constituency, and carries out its activities on the basis of its own resources. The existence of elite pluralism means that power-positions are not 'reserved' for some of its factions. Schumpeter (1976: 269) defines democracy as "an institutional arrangement for arriving at political decisions in which individuals acquire power to decide by means of a competitive struggle for the people's vote". According to Sartori (1987: 151), the essence of democracy as a type of political rule lies in the principle of competition for power-positions, since "no matter how oligarchic the organisation of each minority turns out to be when examined from within, the result of the competition between them is, in the aggregate, democracy". What matters is not the equal possession of power but at least in principle - equal access to it; i.e., the equal opportunity of individuals to occupy power (i.e. elite) positions.

\section{ELITE CONFIGURATION AND POLITICAL DYNAMICS}

Relations between elite factions strongly determine the character of the political setting. This applies also to democratic systems. The character of a political system in fact depends largely on the type of relations among the various political elites (Field et al. 1990; Higley and Burton 1998). This is particularly true in the case of a system transformation in which elites play the role of institution-builders (Kaminski and Kurczewska 1994). As stated above, elite 
settlement that creates consensus over fundamental rules and principles is one of the key prerequisites for the stable functioning of representative democracy. Without at least basic agreement among elites on the key strategic goals of society, consistent policy-making processes can hardly take place. Co-operation between various ideologically opposing political (and not just political) elites is required to maintain the stability of democratic societies, since their integration in the sense of mutual communication and co-operation regarding strategic decisions enables the shaping of a consensus concerning fundamental social principles.

On the basis of the integration and differentiation of elites, Higley et al. (1998: 3-5) distinguish between four different types of elites: a consensual elite (characteristically with a high level of integration and a high level of differentiation), an ideocratic elite (a high level of integration and a low level of differentiation), a fragmented elite (a low level of integration and a high level of differentiation ), and a divided elite (a low level of integration and a low level of differentiation). The configuration of elites is connected to the dynamic of the replacements that are made within it, namely with the method of recruitment to elite positions and the relationships between the different factions of the elite. Higley and co-workers define four patterns of replacements or circulation of elites which differ with respect to their extensiveness (the number of positions subject to replacement, and the thoroughness of the replacements and the mode (speed and non-violence/violence) of replacements): classic circulation with extensive and thorough but peaceful and gradual changes; reproduction circulation peaceful and gradual yet small and shallow changes; replacement circulation thorough, extensive, fast and violent changes; and quasi-replacement circulation - fast and violent but small and shallow changes (Higley and Pakulski 1999; Higley and Lengyel 2000).

Classic circulation can lead to the shaping of the consensual type of the elite and thus to the consolidation of democracy, while the other patterns of replacement lead to configurations of elites that do not constitute the basis for successful democratic development (reproduction suits a fragmented elite and weak or unconsolidated democracy, replacement suits an ideocratic elite and totalitarian or post-totalitarian regime, and quasi-replacement suits a divided elite and an authoritarian regime).

For a coherent and effective policy-making process to take place, consensus in terms of agreement within the political elite regarding the main societal goals and policy orientations is necessary. This applies also to other 'strategic' elites (business, intellectual, religious, etc.) whose role is to maintain the successful functioning of different fields of society (see Keller 1991). Strategic goals can be successfully attained only with the full cooperation of all elite segments. 
While emphasizing the consensus of the elite as a condition of democratic stability, it must be added that both consensus and quasi-solidarity between political elites can also lead to clientism and a lack of responsibility for national development. Examples of this can be found not only in 'new' but also in developed Western democracies. Thus a balance between consensus and competition, and between the reproduction of the elites (which ensures a certain level of stability and foresight) and their circulation (which represents the factor of change and innovation and also a factor of political control), is essential for a successful democracy. "Rotation (and competition) between two or more factions of political elite as well as in the sense of inflow of new actors into other elite segments, is the structural condition sine qua non for the constitution of a polyarchic type of democracy and sustained socioeconomic development" (Adam and Tomšič 2002: 448-49). In this light, the relationship between consensus, conflict and competition should be redefined and a more precise typology should be formulated. As claimed by Diamond (1990), contemporary democracy is a complex system that rests on different and sometimes contradictory principles. Thus the ability to build consensus has to be counterbalanced by the mutual control of different elite factions who must be capable of offering political alternatives that provide a meaningful choice to voters.

\section{ELITES AND DEMOCRATISATION IN FORMER COMMUNIST COUNTRIES}

When dealing with the role of the political elite in the transition process, one has to determine the key characteristics of the social groups that represent (actually or potentially) the leading force in society. Namely, the nature of political elites differs in several ways that include: the mode of recruitment of their members; their relationship toward non-elites; the type of relations within the elite (the level of formalization and inclusion); types of power struggle (aggressiveness or non-violence, intransigence or willingness for dialogue); and prevalent ideological orientations. Further, the nature of any political elite is importantly characterized by its perception of the legitimacy of the authority that determines its mode of political conduct.

Political elites that were formed after the collapse of communist regimes were made up of individuals and groups with varying social and historical origins and ideological orientations: former dissidents of diverse origins, more or less reformist members of the ex-communist nomenclature, members 
of professional groups (so-called technocrats), people from the sphere of the Church, and even some members of pre-war political elites. According to some analysts, transitional political elites display several common traits - particularly, exclusivity towards the non-elite and a lack of professionalism. Consequently, societies at large regard them as unified players that monopolize politics and exercise control over the whole of social life (Agh 1996:45). However, instances of opposition and conflict between various factions of the elite are common; above all, there is competition for the control of key resources by forging different social connections (e.g. the search for alliances, and the creation of various 'coalitions'). This fact indicates that the political elite does not represent a unified group.

The configuration of national elites, meaning the relative position and size of various elite circles in the constellation of power, differs considerably from one post-socialist country to another, and the same is true for the balance between the reproduction and circulation of elites (Dogan 2003; Bozoki 2003, Lengyel et al. 2007) It is precisely the balance and relations among the recently emerged factions of the post-socialist elite that decisively determine the character of political regimes (primarily in terms of the division of power in society; i.e., the level of its dispersal or concentration, as well as social order as a whole).

According to the perspective of democratic elitism, elite settlement in the form of agreement between key elite factions, especially between the reformed part of the communist elite and the newly-formed opposition, was the main condition for the stabilization of democracy in former communist countries from EastCentral Europe. Examples of such development include the 'round tables' in Hungary and Poland in 1989 which resulted in an agreement to carry out free and open multi-party elections in 1990. A similarly gradual and co-operative democratic transition also characterized some other countries such as the Baltic States and Slovenia.

Adherents of the democratic elitism approach who have studied democratic transformation in this region detect a division between East Central Europe, on the one hand, and Eastern and South Eastern Europe on the other with regard to the configuration of the political elite (Higley et al. 1998; Higley and Pakulski 1999). In the former, the consensual type became prevalent, while the latter became dominated by fragmentation and division. Differences in elite configuration had a significant impact on the functioning of democracy. Countries from East Central Europe managed to establish consolidated democracies and a stabilized political space. On the other hand, democracy remained unconsolidated in Eastern and South Eastern European countries, with a high level of political instability, and some even experienced the return of authoritarianism. 


\section{CHARACTERISTICS OF POST-COMMUNIST POLITICAL SYSTEMS}

The main aim of countries that underwent post-communist transformation was to carry out political, economic, social and cultural modernization and thus to overcome their status at the European (semi) periphery which has characterized such societies for centuries (Janos 2000). This refers also to the establishment of a democratic system of governance. In this regard, some of those countries new members of the EU from East-Central Europe - managed to establish the key institutional mechanisms necessary for successful democratic life (see, for example, Adam et al. 2005).

In formal terms, the party systems of former communist countries resemble those of the West. The parties also largely adopted the basic organizational principles and styles that their counterparts in established democracies have in place (van Biezen 2003). Many of them are members of European party associations.

However, the social basis that determines their structuration is different in some important aspects that are related to the specifics of the modernization process. As stated by Evans and Whitefield (1993: 522), "communism deprived individuals of institutional or social structured identities from which to drive political interests, other than those of the nation or mass society". Political space in most of these countries is still characterized by relative instability and volatility. This is mostly the consequence of the weak profiles and identities of many political parties that have considerably hindered them in establishing a stable electoral base (Baylis 1998). This is reflected in weak linkages between party elites and their constituencies (Lewis 2001). Political parties in postcommunist countries, when compared to their counterparts in established democracies of Western Europe, lack mass memberships - certain exceptions include some post-Communist or former satellite parties (Cabada 2013:81).

The ideological focus or self-identification of many political parties in East Central Europe is often very shallow and formal, their programs are often very vague and incomprehensive, and such parties are keen to switch their policy orientations if they expect political benefits from such conduct. Some of them have undergone a significant transition in terms of ideological profile. ${ }^{2}$ Ideological 'emptiness' particularly holds true for 'niche parties'. Parties of

2 One obvious example is the current ruling Hungarian party Fidesz, which evolved from a liberalcentrist-oriented party to a strongly conservative and nationalistic one. Some of its orientations have changed completely; for example, attitudes toward Russia: once it was fiercely anti-Russian, now it is pro-Russian. Interestingly, this happened under the same leader - Victor Orban - testifying to the 'flexibility' of his personal affiliations. 
this type that reject the traditional class-based orientation of politics and which transcend socio-economic cleavage, and that are also - unlike traditional 'catchall' parties - focused on a narrow set of non-economic issues (Meguid 2005; Adams et al. 2006; Wagner 2012) are even more numerous in this region than in Western Europe. In this regard, they differ from their Western counterparts which are often very coherent and focused in terms of ideological orientations (the Italian Five Star Movement is one exception). Unlike the former, they build their public appeal on the general criticism of established political parties and the 'character' of their leaders. The irony is that such parties often transform themselves into mainstream ones (examples include Smer in Slovakia, ANO 2011 in the Czech Republic, and Positive Slovenia in Slovenia).

Political actors in general and political parties in particular are often criticized for their desire to take control of various social systems, mostly those that could contribute to the conservation or obtaining of positions of power. For example, Attila Agh (1996: 55) speaks about "overparticisation", which refers to the aspirations of political parties to exclude other actors from political life. This "partitocracy" is not so much an expression of the parties' strength, but of their weakness; i.e., their weak intellectual and organizational potential (which they try to 'compensate' for by 'borrowing' resources from other areas) (Cabada and Tomšič 2016). In any case, such practices strongly contribute to the low confidence and bad image of such political parties in the eyes of the public, regardless of their ideological orientation.

Weak links between parties and society, coupled with a lack of democratic experience, as well as with the unresponsive and irresponsible conduct of political elites, results in the high level of public distrust of political parties. We may speak about strong 'anti-party sentiments' (Fink-Hafner 1995). This affects political participation. Voter turnout is now on average considerably lower than in Western Europe, and is even decreasing in some 'new democracies'.

\section{DECONSENSUALISATION AND DECONSOLIDATION}

The political space in former communist countries is still more fluid compared to that of established Western democracies. Moreover, in the last few years we can speak about the destabilization of political space and the deconsolidation of political parties. This change is related to the relationship between different elite factions, prevailing ideological patterns, and changes in the political conduct of key players. 
The political life of the new democracies is characterized by the rise of personbased politics. There are a number of features of these countries that create fertile conditions for the personalization of political life. The low level of trust of citizenry in traditional political agents, especially political parties, ${ }^{3}$ opens the door to a non-party politics which is not based on a coherent ideology, and the elaboration of party programs structured around the personal traits of particular political actors. In such circumstances, the personal appeal of political leaders often comes into play, since it can overcome the weaknesses of their parties. Many parties, radical as well as mainstream, have contained (or now contain) strong characters such as Fidesz's Victor Orban in Hungary, or the Kaczynski brothers of the Law and Justice party in Poland. Moreover, many politicians build their appeal on an anti-party or even anti-political platform (as is the case with Victor Uspaskich in Lithuania, Zoran Janković in Slovenia, and Andrej Babiš in Czech Republic). These individuals entered the political space from the business sphere and during their campaigns severely criticized the established political parties, proclaiming that their different, more 'managerial' approach to governance would wipe away the malfunctions of established politics. This approach is typical of many newly-formed political organizations.

The rise of person-based politics came about in a situation characterized by the poor performance of established political parties and their governments. The low administrative efficiency of these governments was accompanied by their lack of responsibility (Tomšič and Prijon 2013). The bad image of political institutions, especially political parties, regardless of their ideological orientation, became predominant in the assessments of the population. The trend to a decrease in trust of political institutions is evident in many Western democracies, but is more profound in the new democracies. Among them, political parties are among the most distrusted (Makarovič and Tomšič 2015). There are many behaviors of established political actors, such as ideologisation, incompetence, clientism, corruption, and other dysfunctional practices, which contribute to such negative sentiments. In such a climate, 'new faces' are able to gain popularity, especially those who build their campaigns on personalized and sometimes 'non-political' platforms.

High volatility is reflected in the increasing occurrence of highly personalized new parties which are successful in one election, but usually become marginalized or even disappear from the political scene in a short time, being replaced by 'newer' parties (Haughton and Deegan-Krause 2015). We can witness political destabilization even in the countries considered to have rather stable political

3 According to the Eurobarometer from May 2017, trust in political parties is, in all countries of the region - with the exception of Hungary - below the EU average. 
and party systems - such as the Czech Republic and Slovenia. This is reflected in the increasing frequency of pre-elections and changes of government - for example, in Slovenia the last two elections took place before the regular term of office had expired, and three governments have been exchanged in the last five years.

Political destabilization is coupled with the deconsolidation of party space. The latter is related to the above-mentioned weaknesses of political parties in these new democracies. We claim that there is no country in East-Central Europe with a party system in which a major political role is played by two parties, one left and one right of center, that continuously exchange power positions - as is usually the case in established Western democracies. Although the left-right divide is rather strong in this region (unlike in most former Soviet republics where it is more or less irrelevant), parties at both poles struggle to establish firm and long-term political support. ${ }^{4}$ It seemed that the Czech Republic would be an exception to this trend, since during the first two decades after the democratic transition the political space was dominated by the center-rightist Civic Democratic Party and the center-leftist Czech Social Democratic Party (one or the other had led every government coalition since 1992). However, the former experienced a significant defeat in the 2013 parliamentary elections, their support ranking them in fifth place among political parties, at less than $8 \%$ (down from more than $20 \%$ in the 2010 election), gaining the party only 16 seats in parliament (compared to the previous election, it lost 37 seats). With this, the Civic Democratic Party lost its primacy on the right of the political space.

Power-relations within political elites still strongly vary in the region. There are countries in which the domination of the rightist faction is evident (meaning such governments were in place for most of the transition period), including Poland, Hungary, Estonia and Latvia, while the leftist faction prevails in Slovenia. In others, the situation in rather unclear either due to the presence of mixed government coalitions (e.g. the coalition of social democrats and radical nationalists in Slovakia), or due to participation in the former by parties whose ideological orientation is unclear (Andrej Babiš' ANO 2011 in the Czech Republic).

In some countries we can witness a shift in power relations over time. For example, in Poland and Hungary, the right and left used to periodically take power until the previous decade, while later the right become dominant. In Poland, the major role is now played by the traditionalist/nationalist Law and

4 It is not unusual for government parties to experience electoral losses of a magnitude that they are eliminated from Parliament. For example, in the 1997 elections in Poland, both members of the government coalition remained outside the Sejm (the lower house). 
Order party and the liberal-conservative Civil Platform, while in Hungary the shift went even further to the right, with the nationalist and Euro-sceptic Fidesz controlling government and the extreme-rightist Jobbik as its main 'alternative'.

Ideological polarization within the political elite (and wider) remains one of the main features of political life. Conflicts of a symbolic nature (attitudes toward communism, nation, religion etc.) are still very prominent and often determine political dynamics. Left-right positioning is usually more related to cultural/identity issues than to economic ones. However, conflicts of a symbolic nature are often conditioned by the interests of their protagonists, and can thus serve as a means of (de)legitimizing existing power relations and exercising control over material resources (Tomšič 2016). For example, conflicts that result from a different understanding and assessment of the communist past and the nature of the former regime can largely be understood as the efforts made by various factions of the political elite to prove their entitlement to their leading positions in society.

This polarization is connected to the rise of populism, which can be perceived as a system of beliefs and guiding principles that glorify the majority of people in opposition to one leading minority - depicted in terms of a harmful 'other' which the former attempts to deprive of their rights, dignity, voice, sovereignty, values, wellbeing, etc. (Albertazzi and McDonnell 2008; Mudde 2004). Antielitist and anti-European populism, usually manifested in the form of the abovementioned, person-based politics and which can be perceived as the revolt of disappointed 'masses' against 'unresponsive' established elites (both at a national and EU level) (Krastev 2007), further undermines the conditions for a consensus-based political process.

There are still elements of consensualism among political elites from the region, particularly with regard to the external institutional environment. Based on the empirical analysis of INTUNE (2007 and 2009) and ENEC (2014) data, ${ }^{5}$ we cannot confirm any significant loosening of the pro-European consensus within the political elites in EU countries from CEE. ${ }^{6}$ Differences with regard to attitudes towards the European Union do not match the left-right ideological divide, but divide between moderate and extremist parties. The vast majority of the moderate left and moderate right see no danger in EU integration (either in terms of its impacts on culture or the welfare system). However, growing disagreement between EU institutions and governments of 'Eastern' EU members about issues such as migration, coupled with the poor management of

5 One should remember that from this group of countries, only Hungary, Lithuania and Slovenia (ENEC) were included in the surveys.

6 The exception is Hungary, where the 'Orbanisation' of Hungary implies a clear Euro-sceptic turn. 
these issues could lead to the rise of Euroscepticism and thus a deterioration in the pro-European consensus.

\section{DETERIORATION IN THE QUALITY OF DEMOCRACY}

EU accession did not automatically boost democratic development. On the contrary, we can observe stagnation or even regression in terms of the quality of democracy. It appears that young domestic democratic institutions are not able to prevent this trend. In some cases, it seems that the progress that was achieved in a quarter of a century of post-socialist development could be lost in a much shorter period of time.

The lack of progress in terms of democratic achievement has been captured in comparative surveys such as the Nations in Transit (prepared on a yearly basis by Freedom House) which contains an evaluation of the political process in former communist countries from Central and Eastern Europe. Considering the period from 2004 onwards (when these countries joined the EU), the 'democracy score' improved only in two countries - Latvia and the Czech Republic (although since 2008 it has worsened) - while in others, it deteriorated in a more or less significant way (see Table 1). The most severe decrease took place in Hungary (from 1.96 in 2004 to 3.54 in 2017), followed by Poland and Slovakia. ${ }^{7}$ In the first, we can observe a continuous deterioration in democratic conditions as measured by this index. The position of Hungary in the group of 'consolidated democracies' regressed even further, leaving it in the group of 'semi-consolidated democracies'.

\footnotetext{
7 'Democracy score' consists of following elements: electoral process, civil society, independent media, national democratic governance, local democratic governance, judicial framework and independence, and corruption. (Starting with the 2005 edition, Freedom House introduced separate analysis and ratings for national democratic governance and local democratic governance to provide readers with more detailed and nuanced analysis of these two important subjects.) The assessment figures range from 1 to 7 . Lower figure indicates higher scores for democracy(https:// freedomhouse.org/report/nations-transit-methodology).
} 
Table 1: Democracy score in countries from East-Central Europe (2004-2017) $)^{8}$

\begin{tabular}{|c|c|c|c|c|}
\hline \multicolumn{5}{|c|}{ Democracy score } \\
\hline & 2004 & 2008 & 2012 & 2017 \\
\hline Bulgaria & 3.25 & 2.86 & 3.14 & 3.29 \\
\hline Croatia & 3.83 & 3.64 & 3.61 & 3.71 \\
\hline Czech Republic & 2.33 & 2.14 & 2.18 & 2.25 \\
\hline Estonia & 1.92 & 1.93 & 1.93 & 1.93 \\
\hline Hungary & 1.96 & 2.14 & 2.86 & 3.54 \\
\hline Latvia & 2.17 & 2.07 & 2.11 & 2.04 \\
\hline Lithuania & 2.13 & 2.25 & 2.29 & 2.32 \\
\hline Poland & 1.75 & 2.39 & 2.14 & 2.57 \\
\hline Romania & 3.58 & 3.36 & 3.43 & 3.39 \\
\hline Slovakia & 2.08 & 2.29 & 2.50 & 2.61 \\
\hline Slovenia & 1.75 & 1.86 & 1.89 & 2.04 \\
\hline
\end{tabular}

Source: Nations in Transit 2004, 2008, 2012, 2017

At least in some cases we can witness the reversion of (semi)authoritarian practices such as exertion of control over the media, and the undermining of the principles of the rule of law (Bugarič 2015; Bugarič and Kuhelj 2015; Lengyel and Ilonszki 2012). The latter is especially one of the most problematic points of the post-communist transformation. In some cases, assaults on the courts (constitutional courts and other 'regular' courts) have already transformed once-powerful veto players into 'toothless' legal actors (Bugarič and Ginsburg 2016). This deterioration in judiciary independence holds particularly true of Hungary and Poland. Both countries are facing repeated criticism and condemnation, not only from domestic and international civil society but also from the European Commission and the European Parliament for undermining the autonomy of rule-of-law institutions, as well as other societal subsystems. ${ }^{9}$ There are also other obstacles to the functioning of the rule of law that are often not detected by comparative surveys. In some countries from East-Central Europe, the judiciary and other elements of the state apparatus are still strongly influenced by members of the former communist regime whose mentality presents a significant obstacle to the performance of these institutions in terms of the protection of human rights

8 Bulgaria, Romania (2007) and Croatia (2013) joint the EU later.

9 For example, a legislative change in the field of higher education introduced by Hungarian authorities undermined the position of privately funded Central European University (CEU), one of the most prestigious institutions in the field of humanities and social sciences in this part of Europe. At the time of writing, their academic freedom remained in grave danger. 
and liberties (Tomšič 2017). Furthermore, there is evidence of the severe violations of these rights, even at the highest levels of the judicial structure. ${ }^{10}$

\section{THE IMPACT OF THE CRISIS}

The perception is widespread that the crisis created fertile soil for political destabilization. To be sure, first the financial and later the 'migrant crisis' and the poor performance of European institutions in dealing with these gave strong impetus to populist, anti-elitist and establishment political forces. The rise of anti-migrant sentiments increased the attractiveness of parties who blamed the establishment (particularly European institutions) for problems related to the immigration of people from the Middle East and Africa. However, discontent with the socio-economic situation in East-Central Europe, and especially with the conduct of political elites, begun to grow before the outbreak of the crisis. Sometimes this manifested in mass protests, as was the case in Hungary in 2006 after a recording became public of the incumbent Prime Minister Gyurcsany admitting to lying about economic conditions. However, it is not the economic situation in terms of how the national economy performed during the crisis that is the sole (or not even the major) determinant of citizens' attitudes toward established political elite. An example of this is Poland, which performed well during the crisis (the only EU country with positive economic growth throughout the crisis period) but the ruling elite in the form of Civil Platform, which was obviously efficient in coping with economic challenges, nevertheless, lost a significant share of popularity and experienced a severe defeat at the 2015 parliamentary elections. Similar is the effect of the migrant crisis. The strongest anti-migrant sentiments and the firmest rejection of migrant quotas comes from countries with a small number of refugees and negligible Muslim populations.

The impact of the crisis on relations between different elite factions is thus indirect at best. The significant ideological polarization that has increased in some cases is predominantly determined by 'internal' factors. The gap between the 'winners' and 'losers' of the transition still plays an important role in the political dynamics of these countries, as do unfinished issues from the

10 One of the most obvious examples of such malign practices is the Slovenian 'Patria case', where the former Prime Minister and the leader of Slovenian Democratic Party (the largest centerright(ist) party in the country), Janez Janša, was sentenced and imprisoned in 2014 on the basis of weakly grounded accusations of 'reception of the promise of the bribery' in a public procurement tender for armored-cars from the Finnish manufacturer Patria. The sentence was finally annulled by the Slovenian Constitutional court. 
recent past. In the context of weak institutional performance (particularly the institution of the rule of law), this situation inhibits the potential for political cooperation and dialog between different elite factions.

\section{CONCLUSION}

Bearing in mind above-mentioned developments, one may question the real strength of the consensus between elite factions in the countries of East-Central Europe. As stated by Baylis (2012: 104), "given the inherent ambiguity of the concept of 'elite consensus', observers would be well-advised to be cautious about assigning it too quickly after a major political, social, or economic upheaval". How persistent was elite settlement initially? And how 'deep' was the mutual agreement between elite factions about the main norms and principles of political conduct? The two countries that used to be called out as examples of successful elite settlement- Hungary and Poland ${ }^{11}$ - are now perceived as those countries in which the most evident backsliding of democracy is taking place (Greskovits 2015). Phenomena that are spreading throughout the region, such as persistent and even increasing ideological polarization, treating political opponents as 'enemies', and the rise of anti-elitist populism, show that the initial elite consensus was rather 'thin': it referred to the formal aspects of regime transition rather than to deeply rooted democratic values. In some cases, as in Slovenia, alleged elite consensus (supposedly existing in the 1990s) was in fact a quasi-consensus, since what appeared as broad agreement about key policy issues and types of socio-economic regulation was the expression of the ideological hegemony of one elite faction (Adam and Tomšič 2012).

Political polarization and the deconsolidation of political space are not only 'Eastern' phenomena, meaning they are not 'reserved' for the 'new democracies' of Central and Eastern Europe. We are now also witnessing the rise of anti-elitist and anti-establishment sentiments and political populism in established Western democracies. However, in countries where institutions especially those in charge in the rule of law - are weak, and thus inefficient, such tendencies are more detrimental. Even though the restoration of classical authoritarianism is unlikely, the situation shows that the sustainable development of democracy should not be perceived as self-evident. The same is the case with elite consensus. For the latter to persist, institutional conditions that enable pluralism, the dispersal of resources, and the balance of power are necessary.

11 See to this, for example, Higley et al., ed., 1998.

CORVINUS JOURNAL OF SOCIOLOGY AND SOCIAL POLICY VOL. 8 (2017)3S 
On this basis, potential competition and cooperation between the various elite factions on an equal basis is possible.

\section{REFERENCES}

Adam, Frane - Kristan Primoz - Tomšič, Matevž (2009), "Varieties of capitalism in Eastern Europe (with a special emphasis on Estonia and Slovenia)", Communist and Post-communist Studies Vol. 42, No. 1, pp. 65-81. Adam, Frane - Matej Makarovič - Borut Rončević - Matevž Tomšič (2005), The Challenges of Sustained Deevelopment, Budapest, New York, The CEU Press.

Adam, Frane - Matevž Tomšič (2012), "The Dynamics of Elites and the Type of Capitalism: Slovenian Exceptionalism?”, Historical Social Research 37, 2, 53-70.

Adam, Frane - Matevž Tomšič (2002), "Elite (Re)configuration and Politicoeconomic Performance of Post-communist Countries", Europe-Asia Studies Vol. 54, No. 3, pp. 365-383.

Adams, James - Michael Clark - Lawrence Ezrow - Garret Glasgow (2006), "Are Niche Parties Fundamentally Different from Mainstream Parties? The Causes and the Electoral Consequences of Western European Parties' Policy Shifts, 1976-1998". American Journal of Political Science Vol. 50, No. 3, pp. 513-529.

Agh, Atilla (1996), "From Nomenklatura to Clientura: The Emergence of New Political Elites in East Central Europe", in: Pridham, Geoffrey - Paul Lewis. eds., Stabilizing Fragile Democracies, London, Routledge, pp. 46-68.

Albertazzi, Danielle - Duncan McDonnell (2008), "Introduction: The Sceptre and the Spectre", in: Albertazzi, Danielle - Duncan McDonnell, eds., TwentyFirst Century Populism. The Spectre of Western European Democracy, Houndmills, Basingstoke, Palgrave Macmillan, pp. 1-15.

Baylis, Thomas (2012), "Elite Consensus and Political Polarization: Cases from Central Europe", Historical Social Research Vol. 37, No. 1, pp. 90-106.

Baylis, Thomas (1998), "Elites, Institutions, and Political Change in East Central Europe: Germany, the Czech Republic, and Slovakia", in: Higley John - Jan Pakulski - Wlodimierz Wesolowski, eds., Postcommunist Elites and Democracy in Eastern Europe, London, Macmillan Press Ltd., pp. 107-130. Best, Heinrich - John Higley (2010), "Introduction: Democratic elitism Reappraised", in: Heinrich Best - John Higley, eds., Democratic Elitism. New Theories and Comparative Perspactives, Leiden, Boston, Brill, pp. 1-22. 
Bozoki, Andras (2003), "Theoretical Interpretations of Elite Change in East Central Europe", Comparative Sociology Vol. 2, No. 1, pp. 215-247.

Bugarič, Bojan (2015), "A Crisis of Constitutional Democracy in PostCommunist Europe: 'Lands In-between' Democracy and Authoritarianism", International Journal of Constitutional Law Vol. 13, No. 1, pp. 219-245.

Bugarič, Bojan - Tom Ginsburg (2016), "The assault on postcommunist courts. Journal of democracy" Vol. 27, No. 3, pp. 69-82.

Bugarič, Bojan - Alenka Kuhelj (2015), "Slovenia in crisis: A tale of unfinished democratization in East-Central Europe", Communist and Post-communist Studies Vol. 48, No. 4, pp. 273-79.

Cabada, Ladislav (2013), “"Parties with No Members?': How to Ensure Political Participation in East Central Europe", in: Demetriou, Kyriakos N., ed., Democracy in Transition. Political Participation in the European Union, Heidelberg, New York, Dordrecht, London, Springer, pp. 77-94.

Cabada, Ladislav - Matevž Tomšič (20016), "The Rise of person-based politics in the new democracies: the Czech Republic and Slovenia. Politics in Central Europe", Politics in Central Europe Vol. 12, No. 2, pp. 29-50.

Dahl, Robert (1989), Democracy and its Critics, New Haven, London, Yale University Press.

Dahl, Robert (1956), A Preface to Democratic Theory, Chicago, Chicago University Press.

Diamond, Larry (1990), "Three Paradoxes of democracy", Journal of Democracy Vl. 1, No. 3, pp. 48-60.

Dogan, Mattei (2003), "Introduction: Diversity of Elite Configurations and Clusters of Power", Comparative Sociology Vol. 2, No. 1, pp. 1-15.

Etzioni-Halevy, Eva (1990), "The Relative Autonomy of Elites: The Absorption of Protest and Social Progress in Western Democracies", in: Alexander, Jeffrey C. - Piotr Sztompka, eds., Rethinking Progress, Boston, Unwin Hyman, pp. 202-225.

Etzioni-Halevy, Eva (1993), The Elite Connection: Problems and Potential of Western Societies, Cambridge, Polity Press.

Euromabrometer, May 2017, European Commission http://ec.europa.eu/ commfrontoffice/publicopinion/index.cfm/Survey/getSurveyDetail/ instruments/STANDARD/surveyKy/2142

Evans, Geoffrey. - Stephen Whitefield, (1993): "Identifying the Bases of Party Competition in Eastern Europe", British Journal of Political Science Vol. 23, No. 4, pp. 521-548.

Field, G. Lowell - John Higley, John - Michael Burton (1990): "A New Elite Framework for Political Sociology", Revue Europeene des Sciences Sociales No. $88,149-181$. 
Fink-Hafner, Danica (1995), “Antistrankarsko občutje ob demokratičnem prehodu" [Anti-party sentiments in democratic transition], in Toš, Niko (ed.), Slovenski izziv II [Slovenian challnege II], Ljubljana, FDV, pp. 181-204.

Greskovits, Bela (2015), "The Hollowing and Backsliding of Democracy in East Central Europe", Global Policy Vol. 6, No. 1, pp. 28-37.

Haughton, Tim - Kevin Deegan-Krause (2015), "Hurricane Season: Systems of Instability in Central and East European Party Politics", East European Politics and Societies and Cultures Vo. 29, No. 1, pp. 61-80.

Higley, John - Michael Burton (1998), "Elite Settlements and Taming of Politics". Government and Opposition Vo. 33, No. 1, pp. 98-101.

Higley, John - Micheal Burton (2006), Elite Foundations of Liberal Democracy, Oxford, Rowman \& Littlefied Publishers.

Higley, John - György Lengyel (2000), "Elite Configuration after State Socialism", in: John Higley - György Lengyel, eds., Elites after State Socialism. Lanham: Rowman \& Littlefield Publishers, pp. 1-20.

Higley, John - Jan Pakulski, Jan - Wlodzimierz Wesolowski(1998), "Introduction: Elite Change and Democratic Regimes in Eastern Europe", in: John Higley - Jan Pakulski - Wlodzimierz Wesolowski, eds., Postcommunist Elites and Democracy in Eastern Europe. London, Macmillan Press Ltd., pp. 1-33.

Higley, John - Jan Pakulski (1999), "Elite power games and democratic consolidation in Central and Eastern Europe", Historical Social Research Vol. 37, No. 1, pp. 292-319

Hoffmann-Lange, Ursula (1992), "Elite v modernih demokracijah" [Elites in modern democracies]. In: Adam, Frane (ed.): Politika kot poklic [Politics as profession]. Ljubljana: KRT 1992, 91-107.

Janos, Andrew (2000), East Central Europe in the Modern World. Stanford, Stanford University Press.

Kaminski, Antoni - Joana Kurczewska (1996), "Strategies of Post-Communist Transformation. Elites as Institution-Builders", in: Grancelli, Bruno, ed., Social Change and Modernization. Lessons From Eastern Europe, Berlin, De Gruyter, pp. 131-152.

Keller, Suzanne (1991): Beyond the Ruling Class. Strategic Elites in Modern Society. New Brunswick: Transaction Publishers.

Krastev, Ivan (2007), "Is East-Central Europe Backsliding? The Strange Death of the Liberal Consensus", Journal of Democracy Vol. 18, No. 4, pp. 56-63.

Lengyel, Gyorgy et al. (2007): Political Elites in Central-Eastern Europe. Budapest: Friedrich Ebert Stiftung.

Lengyel, György - Gabriela Ilonszki (2012), "Simulated Democracy and Pseudo-Transformational Leadership in Hungary", Historical Social Research Vol. 37, No. 1, pp. 107-126. 
Lewis, Paul (2001), "The Third Wave of Democracy in Eastern Europe", Party Politics Vol. 7, No. 5, pp. 643-65.

Makarovič, Matej - Matevž Tomšič (2015), "Democrats, authoritarians and nostalgics: Slovenian attitudes toward democracy", Innovative issues and approaches in social sciences Vol. 8, No. 3, pp. 8-30.

Meguid, Bonnie M. (2005), "Competition between Unequals: The Role of

Mainstream Party Strategy in Niche Party Success", American Political Science Review Vol. 99, No. 3, pp.347-359.

Mills, C. Wright (1956), The Power Elite, Oxford, Oxford University Press.

Mudde, Cas (2004), "The Populist Zeitgeist", Government and Opposition Vol 39, No. 4, pp. 541-563.

Nations in Transit 2004, 2008, 2012, 2017, Freedom House https://freedomhouse. org/report-types/nations-transit

Sartori, Giovani (1987), The Theory of Democracy Revisited, New Jersey, Chatham House Publishers.

Schumpeter, Joseph A. (1976), Capitalism, Socialism and Democracy, London, George Allen \& Unwin Ltd.

Tomšič, Matevž (2017), Building a common European identity: between unity and diversity, in: Novotny, Vít, ed., Unity in adversity: immigration, minorities and religion in Europe. Brussels, Wilfried Martens Centre for European Studies, pp. 29-36.

Tomšič, Matevž (2016), Elites in the New Democracies, Frankfurt am Main, Peter Lang.

Tomšič, Matevž - Prijon, Lea (2013), "Person-based politics in Italy and Slovenia: comparing cases of leadership's individualisation", International Social Science Journal Vol. 64, No. 213/214, pp. 237-248.

Vogel, Lars - Juan Rodriguez-Teruel (2016), "Staying on Course in Turbulent Times: National Political Elites and the Crisis of European Integration", Historical Social Research, Vol. 41, No. 4, pp. 7-37.

Wagner, Markus (2012), "Defining and measuring niche parties", Party Politics Vol. 18, No. 6, pp. 845-864.

Weber, Max. 1978 [1919], "Politics as a Vocation", in: Runciman, W. G., ed. Max Weber, Selections in Translation, Cambridge, Cambridge University Press, pp. 212-22. 